\title{
Paideusis
}

\section{"Women Teaching, Women Learning: Historical Perspectives" (Elizabeth M. Smyth \& Paula Bourne (Eds.))}

\section{Kristina R. Llewellyn}

Volume 17, Number 1, 2008

URI: https://id.erudit.org/iderudit/1072470ar

DOI: https://doi.org/10.7202/1072470ar

See table of contents

Publisher(s)

Canadian Philosophy of Education Society

ISSN

0838-4517 (print)

1916-0348 (digital)

Explore this journal

Cite this review

Llewellyn, K. (2008). Review of ["Women Teaching, Women Learning:

Historical Perspectives" (Elizabeth M. Smyth \& Paula Bourne (Eds.))]. Paideusis,

17(1), 71-73. https://doi.org/10.7202/1072470ar 
Review of

\title{
Women Teaching, Women Learning: Historical Perspectives
}

by Elizabeth M. Smyth E Paula Bourne (Eds.), Toronto: Innana Publications E Education, 2006

\author{
KRISTINA R. LLEWELLYN \\ University of Ottawa, Canada
}

In a 1986 issue of History of Education Quarterly, Patrick Harrigan argued that Canadian scholarship was taking the international lead in its attention to women and education. ${ }^{1}$ He noted the pioneering work of Alison Prentice as a primary reason for this trend. Prentice's critical scholarship over more than 40 years has turned the study of women and education from a trend to an established field. Elizabeth M. Smyth and Paula Bourne have edited this collection, Women Teaching, Women Learning: Historical Perspectives, to honour the academic contributions of Alison Prentice. Her large body of work as a feminist in Canadian history has covered topics from the gendered bureaucracy of schooling to women's professional influence of our historical memory. In addition to publishing, Prentice's teaching and supervision has nourished those in the field to re-conceptualize the boundaries of schooling in relation to the State. Her cross-generational and international students and colleagues, who author this edited collection, demonstrate that the study of women and education necessitates analysis of difficult social issues, including community development, domestic ideology, and contemporary curriculum and achievement debates. Influenced by the interdisciplinary, feminist methods Prentice has employed to challenge the historical 'record,' the authors produce strong evidentiary narratives to make women's past experiences of teaching and learning "real, personal and relevant" (12).

The first section of the collection pays particular respect to Prentice's research with its emphasis on the lives of women teachers. Marjorie Theobald sets the stage for this section, despite being the second chapter in the collection. Theobald illustrates through an overview of her historical research that "in a profession that depends crucially upon the labour of women, it is imperative that policy makers understand the wider context of women's lives" (81). Her chapter is a response to a 1998 Australian Senate report that refutes gender as a point of inquiry when addressing the disturbingly low status and morale of teachers. Theobald argues that the Western liberal democratic State has inherent difficulties with lady teachers who as independent and intelligent professionals represent a threat to male dominance. Theobald shows that nineteenth and twentieth century legislation and social norms ensured women taught under male governance and were confined to separate and often temporary career paths. She warns that degradation of today's well-educated women in teaching will push them, like it has nurses, to pursue other career options.

The remaining chapters in this section illustrate the innovative tools historians use to uncover women's leadership within the patriarchal structures of teacher education. Coulter advocates for a

\footnotetext{
${ }^{1}$ Patrick J. Harrigan, "A Comparative Perspective on Recent Trends in the History of Education in Canada," History of Education Quarterly, 26, 1 (1986): 79-80.

(C) Copyright 2008. The author, Kristina Llewellyn, assigns to Paideusis the right of first publication and educational and non-profit institutions a non-exclusive license to use this document for personal use and in courses of instruction provided that the article is used in full and this copyright statement is reproduced. Any other usage is probibited without the express permission of the author.
} 
careful reading of textbook writing to understand Canadian progressive educator Donalda Dickie. When denied formal positions of authority, Dickie used textbook writing as a "power of practice" (23) that shaped the enterprise method of teaching and citizenship concepts for student learning in the early twentieth-century. Coulter argues that the legacy of women like Dickie will be overlooked without scholarly reconsideration of leadership as synonymous with administration. Dianne Hallman and Anna Lathrop use Prentice's method of comparative biography to examine the career management strategies of Mary G. Hamilton (1883-1972) and Irene Poelzer (1926-). Hallman and Lathrop contend that these women, living at respective ends of the twentieth-century, used "scholarly passion" to "foster supportive networks for women as the key antidote to the chilly climate of academe" (46): Hamilton, through a separatist model as principal of Margaret Eaton School, which trained women in physical education, and Poelzer, a professor at the University of Saskatchewan, who developed the first feminist course at a Canadian Faculty of Education. Hallman and Lathrop make the case that women's life stories should remind educators in this era of intellectual commodification that scholarly passion is "caught by persons from persons" (60). Inga Elgqvist-Saltzman writes about introducing student teachers to the passion of nineteenth-century, Swedish religious woman and teacher educator Cecilia Fryxell through an exploration of archival sources. Elgqvist-Saltzman argues that as students gained knowledge of Fryxell's trials to establish girls' schools, including their local teacher training college, they were able to discuss current disciplinary, pedagogical, and character education issues with greater depth and perspective.

Women's power within educational institutions continues to be addressed in the second section of this collection. This set of chapters, however, deals more explicitly with the regulation of women's education through male bureaucracies of state formation. Cathy James' essay looks at the life of Edith Elwood (1875-1931) whose activism in the Canadian settlement house movement laid the groundwork for women's community-based education and the structures of the Canadian welfare state. James contends that Elwood's influence, through women's organizations, was ignored after the state increased control over relief for the poor and the professionalization of social work. The reader is reminded by James' concluding remarks that women, like Elwood, have brought about lasting, national reforms not simply through government establishment but social character. Harry Smaller examines the political rationales for school 'reform' in 1880s Toronto that re-enforced traditional gender and class relations. He shows that calls by male administrators for centralized controls, cost 'downloading,' and school 'efficiencies' translated into increased surveillance of 'problem' working-class children and the work of women teachers. He urges scholars to be critical of current discourses of 'failing' schools that mirror historical 'restructuring' of social difference. Wendy Mitchinson turns our attention to the role of medical discourse in restricting women's education. She stresses that male medical practitioners inserted themselves into the growing education systems of the early twentieth-century by claiming expertise in the physiological limits of women's bodies and thus their learning capabilities. School curriculum needed to prepare girls' bodies for motherhood through the domestic sciences. Too much 'other' education would lead to "diseases of the womb" (166) and immorality for the future 'race.'

The final section of chapters builds upon Mitchinson's theme of domestic boundaries by challenging its static conceptions. These authors focus upon women's active choices to bridge public and private spheres, paid and unpaid labour, as well as formal and informal education. Susan Mann offers a sophisticated essay on the travel lessons of middle-class Canadian girls and women. She contends that travel abroad was a form of continuing education in domestic accomplishments used by women to safely traverse space and enhance their family social status. Domestic ideology, according to Mann, enabled women to "travel without trespassing" (189). Alison Mackinnon similarly argues that higher education allowed her subjects to make and re-make themselves contrary to 1950s conservative domestic ideals in Australia and the United States. The middle-class, white women she studies played with identity, through fantasy or ambition, to negotiate forces that "pulled women into the workplace yet urged them to find fulfillment in domestic life" (208). MacKinnon concludes that women's ability to create plural "selves," at once autonomous and feminine, intellectual and familial, might have 
contributed to a developing feminism that found expression in the 1960s. Cecilia Reynolds uses intergenerational interviews with families of women to describe how the ideology of domesticity changes over time, despite retaining dominant themes about formal schooling and breadwinner status. The narratives, Reynolds observes, reveal individual constructs of gender identity through each woman's "reading of ideologies," adjustments according to economic and social circumstances, and "own sense of what is possible" (230). This final essay in the collection reflects the strength of the book to dispel essentialist claims about gender and education, and encourages readers to view women as complex historical agents.

Such strength would have been enhanced if the collection had more explicitly addressed the intersections of race, class, and sexuality in the education of women. Primary exceptions include Smaller's argument that unrest during industrialization turned officials' attention to socialization of the working class, and Reynold's acknowledgement that women's experiences of school and work may have been very different across ethnic groups. The reader is left to question: Has the educated woman, and female learning communities, been the target of scorn due to perceived or possible rejection of heterosexuality? How have women teachers, along with travelers and textbook writers, participated in the colonial project? What was the relationship between medical practitioners and first-wave feminists with respect to eugenics and women's schooling? These questions may not have been addressed, in part, because of the authors' focus on biographical representation. The gift of biographies is the skill with which historians restore women to the historical record, forced to "reinvent the lives their subjects led" from "what evidence they could find" (26). ${ }^{2}$ Evidence is most often accessible, however, from elite, well-educated women who kept diaries and personal papers or whose records were preserved due to their recognized leadership in state institutions. What have been the gendered learning experiences of domestic servants or young girls in the nineteenth-century and twentieth-centuries? Responses to this question are probably on-going projects thanks to the legacy of Alison Prentice and now the contributors of this collection. These essays, despite calls for a broader subject base, speak to the critical point that women's narratives have a significant educative value. As noted in the introductory chapter, the book makes "real, personal, and relevant" (12), both historically and today, gender equity issues of educational opportunity, definitions of leadership, and concepts of civic engagement. Whether interested in gender studies, history or education, those students and educators who have the pleasure of reading this book will understand that, like Alison Prentice, women have been and will continue to be vital change agents for the improvement of teaching and learning.

\section{References}

Harrigan, Patrick J. "A Comparative Perspective on Recent Trends in the History of Education in Canada." History of Education Quarterly 26, 1 (1986).

Heilbrun, Carolyn. Writing a Woman's Life. New York: Ballantine, 1988.

\footnotetext{
${ }^{2}$ Coulter cites Carolyn Heilbrun, Writing a Woman's Life, (New York: Ballantine, 1988): 31.
} 